\title{
College English Reform and Cultivation of Cross-cultural Competence
}

\author{
Ying $\mathrm{Gu}$ \\ School of Basic Education Beijing Institute of Graphic Communication, \\ Email: guying@bigc.edu.cn

\begin{abstract}
College English teaching, as a compulsory course in higher education, plays an indispensable role in cultivation of talents of our country. The reform of college English has become a major issue of concern to all universities. In order to comply with the tide of social cross-cultural communication, college English teaching requires corresponding changes and reforms. Based on this, this paper focuses on the current situation of College English teaching, and puts forward the relevant strategies of teaching reform and cross-cultural communication ability training, which has a certain guiding significance for the realization of the innovation of College English teaching.
\end{abstract}

Keywords: College English teaching; Reform in education; cross-cultural competence;

\section{INTRODUCTION}

Under the background of globalization, the integration of world culture is more obvious. Cross-cultural communication refers to the process in which different cultural groups communicate with each other on the basis of language learning. It is not only a channel to establish relations through language, but also a bridge for the connection and development between ethnic groups, which has a positive impact on the global development of a country. As an international language, English plays an important role in cross-cultural communication.For college English teaching, the cultivation of intercultural communicative competence in college English classroom is becoming more and more important in the current environment. Teachers should actively explore new teaching modes and improve the level of college English teaching by combining current teaching and talent cultivation requirements and aiming at the deficiencies existing in conventional teaching.

\section{THE IMPORTANCE OF COLLEGE ENGLISH TEACHING REFORM AND THE CULTIVATION OF INTERCULTURAL COMMUNICATION ABILITY}

\section{1 an Important Supplement to Language Learning Language, which plays the role of cultural medium in economic and social development.}

Since students have basically mastered sentence patterns and grammar in English, the focus of learning tasks at the stage of college level is to help students accumulate more English vocabulary and improve their English application ability. However, due to the conventional college English teaching process, the teaching mode and means are relatively fixed, coupled with the current international and domestic market in many fields involving English content, the market has higher requirements for English talents. Changes in the job market bring corresponding teaching reform of college English, which is essentially committed to the cultivation of intercultural communication ability. Teaching reform and the cultivation of intercultural communicative competence is the important supplement of classroom teaching content. Cross-cultural competence plays a key role in the process of economic and cultural exchanges between countries. Moreover, through classroom learning, the process of intercultural 
ability training enables students to master more vocabulary, sentence patterns, thus they have better ability of English expression and application[1]

China's attempt in cross-cultural communication is an important outcome of the development of cultural innovation with the reform and opening up, and has been accelerating its speed and process after the economic opening up. In the early stage of cross-cultural communication in China, scholars mainly focused on English classroom teaching, focusing on the analysis of the relationship between language learning and national culture. With the deepening of college English teaching, the requirements of classroom learning have also put forward new arguments. Instead of focusing on the traditional training of language competence, more attention has been paid to the language-based communicative competence training, which finally extends to the direction of cross-cultural. In terms of the current college English learning in China, many students will encounter difficulties and obstacles in the field of cross-cultural communication, most of which are reflected in the lack of understanding of other countries' cultural knowledge. This phenomenon also gives some hints to the teaching subjects. In order to truly improve the level of students' cross-cultural communication, students must be equipped with the ability to respond to the cultures of other countries and master the corresponding foreign cultural knowledge, so as to apply it to specific practices [2].

\section{2 current situation of College English teaching and research on cross-cultural communication in China}

For college English teaching, there is a collision of different cultures. Therefore, in college English classroom teaching, attention should be paid to the culture of the country and the culture of English-speaking countries, and corresponding teaching reform should be carried out based on the culture of two different language backgrounds, so as to form a unique method of cultivating intercultural communication ability. In order to improve teaching effectiveness, students should fully understand language habits and expressions in different cultural environments and pay close attention to the cultural environment and local culture of English-speaking countries in the process of participating in various learning activities and ability cultivation work [3].But for the moment, quite a lot of college English teaching pay high attention to the foreign culture in carring out activities, while ignoring the local culture and cognition, thus resulting in many deficiencies of Chinese culture. Failing in the fusion of local culture and the English national culture, there are often some misunderstandings in the teaching reform and the cultivation of intercultural communication ability, which cannot guarantee the quality and effectiveness of teaching.

\section{MAIN OBSTACLES IN CROSS-CULTURAL COMMUNICATION COMPETENCE}

\subsection{Cultural Differences}

Although cross-cultural communication is achieved through specific sentences, sentences are ultimately composed of words. The development of Chinese and Western culture is very different, and the meanings of words accumulated in their history are also necessarily very different. For example, the word "dragon" often refers to evil, selfish and greedy images in Western culture, and the images displayed are mainly villains. However, in Chinese culture, the image of "dragon" represents auspiciousness, harmony and luckiness, and is the spiritual sustenance and reliance of millions of people. Moreover, the images in many Chinese novels are mainly positive characters. In addition, the honorific titles accumulated by Chinese traditional culture are very extensive. For the elders, the younger generation should give them specific honorific names, such as grandpa and uncle. Differently, in Western culture, equality of status is emphasized between groups, even in front of relatives, people can address each other directly by name.

\subsection{Differences in thinking}

There are obvious cultural differences between English speaking countries and Our country. Only when we fully grasp the cultural differences in English teaching can we promote the smooth progress of English teaching. Chinese people enjoy the habit of modesty and courtesy; while for some western countries, they are relatively open, and have strong ability to accept new things. Their people are more willing to accept other people's praise. Consequently, the Chinese modest answer tend to cause certain confusions, leading foreigners embarrassed and confused with no knowledge of the real meaning of modest answer. Therefore, in order to avoid this kind of embarrassment caused by cultural differences in English learning, teachers should play an active role in the learning process. For one thing, we should equip students with the knowledge of the difference in the thinking mode between other countries and our mother tongue, helping them establish the breakthrough thinking ability. For anther, teachers need to created certain situation activities ,aiming at creating opportunities to practice their English listening, speaking, reading and writing in cross-cultural communication ability training. For example, the teacher should convey to the students relevant points in the cocktail party. If foreigners want to chat up each other, they will usually start with praise. 
"Your look gorgeous in this dress." I think so, too. Thank you for your appreciation. While, Chinese people tend to be modest with the answer kind like "I think it's normal. That's it." Therefore, in order to promote the reform of college English teaching and the development of intercultural communication ability, it is necessary to eliminate such differences in thinking.

\subsection{Language Differences}

In Chinese, "Have you had dinner yet?" and "What are you going to have for lunch?" are relatively polite expressions, which are only polite greetings. Therefore, under the condition of different languages, differences also exist in a certain context, as a result, both the teaching reform and cross-cultural communication ability training, all need to eliminate the language differences, teachers in the process of college English teaching, to lead the students to fully understand about this aspect of the content, allowing students to differences in Chinese and English language on the basis of learning English, Master more skills about English learning, so as to improve students' oral communication ability.

\section{PRACTICAL MEASURES FOR THE CULTIVATION OF COLLEGE STUDENTS' INTERCULTURAL COMMUNICATION ABILITY}

\subsection{Optimize the teaching faculty}

Although students have more initiative and discourse power in college English learning, the cultivation of their ability still depends to a large extent on the demonstration and guidance of teachers. Therefore, the performance of teachers in intercultural communication ability also determines the quality and efficiency of class to a large extent. In this regard, schools should actively encourage teachers to cultivate their cultural communication skills, and encourage teachers to strengthen foreign exchanges and learning. Cultural exchanges create opportunities and platforms for teachers to communicate with scholars from other countries. For example, the school can allocate a group of foreign visiting scholars every year so that English teachers can study in foreign countries, experience foreign cultures and absorb beneficial experience and value. In this way, teachers can also feel their own teaching defects and make improvements in subsequent classes to avoid empty words without evidence [4].In addition, schools can properly expand the recruitment quota of foreign teachers so that foreign teachers can introduce local culture to students in class, through which students can feel cultural conflicts more directly and intuitively. What's more, school teachers need to communicate with foreign teachers on the difference between Chinese culture and western cultures, absorbing and learning from each other in class experience in order to sum up the possible cognitive conflict and cultural collision points. With these knowledge, more scientific and effective learning methods will come into being and students can understand and accept cross-cultural related knowledge easier.

\subsection{Change traditional teaching methods}

In the current stage of college English teaching, teaching reform is relatively difficult. In order to speed up the process of teaching reform and promote the cultivation of intercultural communication ability, college teachers should actively change their teaching methods in the process of teaching activities, and use new teaching methods to motivate students' learning initiative and enthusiasm. Through the class instruction, students should be able to develop a certain sense of cross-cultural communication in English learning, which simultaneously help to improve students' English application and expression ability. The corresponding teaching in order to cope with the test in the teaching should be definitely avoid. In the process of college English teaching, teachers should attach importance to teaching reform ideologically and comprehensively and ensure the implementation of intercultural communication skills. Teachers should first transmit related content about Western culture to students, and then explain English words and sentence patterns with culture background as a starting point . since English is not our mother tongue, there is no specific environment in English teaching and learning, which increases the difficulty of students' English learning. Some students encounter many problems in English learning due to the limitations of learning ability. If traditional teaching methods are adopted for a long time, students may not be able to integrate into English Classroom Teaching [5].Therefore, in the process of College English teaching, teachers should actively adopt some effective teaching methods and means, speed up the pace of teaching reform through the innovation of teaching methods, and promote the cultivation of students' cross-cultural communicative competence.

\subsection{Innovation of teaching mode}

The improvement of cross-cultural communicative competence lies in practical training and cultivation. Therefore, teachers should break away from the traditional education model. They should not blindly take themselves as the classroom center and help students accumulate experience only through their own knowledge indoctrination. Instead, they should encourage students to understand mistakes, reflect and summarize through their own exercise and attempt. In this regard, teachers should set specific dialogue contents for students, let students simulate in groups, 
and show them in class. At the same time, teachers can also hold dialogue activities for foreign students in the school for students to carry out dialogue and exchange between students and overseas students, which can not only enhance friendship, but also enable students to dig out the differences between eastern and Western cultures [6]. In addition, teachers need to set up phased social practice activities for students according to different teaching themes, so that students can ask their views and opinions on cultural exchange in the form of questionnaire survey or on-site interview, with the whole school teachers and students as the unit, especially foreign students, so that they can put forward suggestions on cultural exchange, and then collect and sort them into a report. Students can systematically express their report contents in the form of speeches or papers and submit them to teachers for reading. This practical activities which are close to life can enable students to practice their oral ability in the process of communication. At the same time, they can also gain more social experience, increase their experience, let them view the cultural differences between the East and the West with a more objective and dialectical attitude, understand that the skills and methods should be paid special attention to in cultural exchanges, to avoid misunderstandings in communication, and promote cultural equality and friendly exchanges.

\section{CONCLUSION}

To sum up, college English as a basic course in tertiary level stands on the key position on talents cultivation. with the change of market environment, China has put forward new requirements for college English teaching reform. It is very reasonable and necessary to insist on the cultivation of intercultural communicative competence in college English teaching. This is a proper way to improve students' language proficiency and an effective measure to cultivate students' cultural sensitivity. In the process of concrete practice, the teacher should fully carry out the basic requirements of cross-cultural communication, focus on the accumulation of culture experience in teaching and research, aiming at enhancing student's ability to cross-cultural communication, improve the overall teaching effectiveness.

\section{ACKNOWLEDGMENT}

Supported by research program of BIGC (Beijing Institute of Graphic Communication, Project Number: 22150120015

\section{REFERENCES}

[1] Sun Yanbo. On College English teaching reform and strategies for cultivating cross-cultural communicative competence [J]. Campus English, 2018 (8): $20-21$

[2] Li Wenzhuo. Discussion on barriers and Countermeasures of College English cross-cultural communication [J]. Journal of Jiangxi Electric Power Vocational and technical college, 2019,32 (4): 95-96

[3] Song Yaping. On the strategies of cultivating intercultural communicative competence in College English Education $[\mathrm{J}]$. Sino foreign communication, 2017 (50): 50-51

[4] Yang Hua, Li Liwen. Action research on integrating cross-cultural competence and College English Teaching $[\mathrm{J}]$. Foreign language and foreign language teaching, 2017 (2): 9-17146

[5] Jin Jingbo. Exploration on the path of College English teaching reform from the perspective of cross-cultural communication $[\mathrm{J}]$. Journal of Heilongjiang Institute of engineering, 2020,34 (6): $72-75$

[6] Duan Yu, Cui Yanqiang. Theoretical connotation and practical direction of new liberal arts construction $[\mathrm{J}]$. Journal of Yunnan Normal University (PHILOSOPHY AND SOCIAL SCIENCES EDITION), 2020,52 (2): 